\title{
Is It Freedom? The Coming About of the EU Directive on Whistleblower Protection
}

\author{
Wim Vandekerckhove ${ }^{1}$ (1)
}

Received: 23 April 2020 / Accepted: 9 February 2021 / Published online: 5 March 2021

(c) The Author(s) 2021

\begin{abstract}
In November 2019 the EU Whistleblower Directive came into force. Whistleblowing has been described as a human right and a freedom fundamental to democracy. But it is not always straightforward to understand concrete cases of reporting wrongdoing in terms of abstract political philosophy. This paper uses a discussion between Berlin and Skinner about what negative freedom is, as a theoretical framework to understand the struggles of a campaigning platform of trade unions and civil society organizations, in the coming about of the EU Whistleblower Directive. The paper is empirically based on a document analysis of two Resolutions in the European Parliament, the European Commission's proposal text, the approved text in the European Parliament, and messages on the listserv of the campaigning platform between February 2017 and April 2019. The paper provides insights on how whistleblowing freedom relates to public interest and autonomy.
\end{abstract}

Keywords Berlin · Freedom · Whistleblowing

\section{Introduction}

This paper considers how whistleblowing relates to freedom. More precisely, I look at the campaigning between 2016 and 2019 around the EU Directive on whistleblower protection (2019/1937) to understand the fragility of one of human's fundamental freedoms, i.e. freedom of expression.

Note that the formulation in the Universal Declaration of Human Rights sees this freedom not only relating to freedom of expressing one's opinion but also freedom to seek, receive and impart information. That is highly relevant for this paper, since whistleblowing is the "disclosure by organization members (former or current) of illegal, immoral or illegitimate practices under the control of their employers, to persons or organizations that may be able to effect action' (Near and Miceli 1985, p. 4). This standard definition of whistleblowing (cf Brown et al. 2014) implies that whistleblowing involves an intentional disclosure of sensitive information to which the whistleblower has insider access.

In business ethics scholarship, much of the research has been related to how much autonomy a worker can have with

Wim Vandekerckhove

w.vandekerckhove@greenwich.ac.uk

1 Centre for Research in Employment and Work (CREW), University of Greenwich, Park Row, London SE10 9LS, UK regard to her whistleblowing (e.g. Bouville 2008; Hassink et al. 2007; Larmer 1992; Tsahuridu and Vandekerckhove 2008; Vandekerckhove and Commers 2003). Is it a duty and if so who might impose an obligation to blow the whistle, or is it permissible, i.e. is it up to a worker to decide freely? What has received far less attention in business ethics scholarship is the question what justifies prohibiting a worker from whistleblowing. That is surprising because it is precisely how the battle over the right to 'receive and impart information' - and thus the freedom of expressionis fought outside of academic scholarship, also in the context of whistleblowing. More than two decades ago, Dworkin and Callahan (1998) found that increased whistleblower protection legislation in the USA was off-set by an increase in employers enforcing secrecy agreements against whistleblowers through court. In a similar argument, Fasterling and Lewis (2014) suggest that whistleblowing on governments might lead to governments closing themselves off from the media and intensify the prosecution of whistleblowers and journalists. It is in that sense that I consider whistleblowing legislation as a battleground for freedom. Between obligation and prohibition, only the position that whistleblowing is permissible leaves the autonomy for whistleblowing with the worker. In this paper, I focus on how legislation attempts to carve out such a 'zone of non-interference' for whistleblowing. More precisely, I look at the argumentative dynamic of 
the documents and campaign culminating in 2019 in the EU Whistleblowing Directive (2019/1937).

Elsewhere (Vandekerckhove 2016) I have argued that between 1978 and 1999 all legislative bills on whistleblowing anywhere in the world framed whistleblower protection as establishing freedom of expression. However, none of these were successful. Only when successive bills rephrased whistleblowing as an anti-corruption tool was it possible to enact whistleblower protection. In countries where the debates started after 2000 law proposals skipped the human rights/freedom of expression phase and went for an anticorruption/anti-fraud rhetoric immediately. Vandekerckhove (2016) notes that the anti-corruption rationale for whistleblower protection is one of efficiency rather than human rights. This changes however around the end of that decade. A number of streams combine into a renewed whistleblowing assemblage that (again) uses a freedom of expression framing. These streams include (Vandekerckhove 2016): (1) growing jurisprudence from the European Court of Human Rights on whistleblowing cases brought under Article 10 (freedom of expression) of the European Convention on Human Rights; (2) a mushrooming of leaks sites following Wikileaks; (3) the work of the Parliamentary Assembly of the Council of Europe (PACE), and specifically its Committee for Legal Affairs and Human Rights, taking up whistleblowing in the context of freedom of expression (e.g. PACE Resolution 1729 (2010), and PACE Doc.13278 (2013)); (4) the 29 principles of the Council of Europe's Recommendation $(\mathrm{CM} / \operatorname{Rec}(2014) 7)$ on the protection of whistleblowers, which provide an excellent framework to evaluate any national whistleblowing regime around the world, and especially serves as a benchmark for the Council of Europe's 47 member states, which includes the 27 EU Member States.

The first two decades of the twenty-first century have seen a boom in whistleblower protection legislation. Globally, between 1978 and 1999, only five countries had adopted such legislation (Vandekerckhove 2006). Between 2000 and 2019 at least twenty additional countries have done so. The transposition of the EU Whistleblowing Directive into the national legislation of the Member States implies that 27 European countries will either introduce, significantly strengthen or at least review their whistleblowing legislation (see http://euwhistleblowingmeter.polimeter.org/ for updates on the transposition).

Reminiscent of the struggle between whistleblowing and secrecy, which Dworkin and Callahan (1998) point at, the development of the EU Whistleblowing Directive gained momentum after the adoption of the EU Trade Secrets Directive in 2016 (2016/943). The next section sketches that background. The section after that presents a description of how whistleblowing campaigners pushed forward their agenda between 2016 and 2019 and what adversity they encountered. Within that section, the paper distinguishes two phases, one where debates focused on delineating the public interest, and the other starting December 2018, focusing on identifying recipients of legitimate whistleblowing.

This paper is not merely descriptive. In the section following the descriptive part, I provide a philosophical discussion of how whistleblowing freedom was fought for. To do that I revisit the work of Isaiah Berlin on negative freedom, and Quentin Skinner's critique of that. Berlin was a professor of social and political theory at Oxford University, and is regarded as one of the most important political philosophers of the twentieth century. Skinner is a historian and is one of the founders of the Cambridge School of the history of political thought. I use Berlin and Skinner to discuss how the two aspects of the campaign-public interest and recipients-relate to freedom and to each other. Berlin and Skinner had somewhat different ideas of freedom; I argue that the nuance in their thinking helps us to grasp the importance of considering both aspects together when discussing whistleblowing legislation.

\section{EU Trade Secrets Directive}

In April 2016, the European Parliament (EP) voted in the EU Trade Secrets Directive (2016/943). That was a highly contested initiative because it legitimized organizational secrecy, not only for its innovations and R\&D but also on nearly anything the organization could argue was part of how it ran its operations. Trade secrets are 'secret information that is of value for its owner because of its secrecy' (Gutfleisch 2018, p. 175). For example, one could argue that tax avoidance schemes are trade secrets because that is precisely what is underpinning the tax advising company's business.

Gutfleisch (2018) writes that protecting trade secrets is a necessary condition for the technological advancement and competitiveness of an economy. Hence why the European Union crucially needed a trade secrets directive to boost R\&D and innovations. However, Gutfleisch (2018) points out that trade secrets are not the same as intellectual property right, like patents, designs or trademarks. Whilst the latter are publicly registered, trade secrets are not and hence do not grant the trade secret owner an exclusive right. Hence there are exceptions to the secrecy of trade secrets. The story of the EU Whistleblowing Directive is, as will become clear in this paper, one of carving out and safeguarding those exceptions to secrecy.

The S\&D group within the European Parliament had voted in favour of the Trade Secrets Directive, yet in a press statement issued on 14 April 2016, the S\&D group describes itself as a 'strong negotiator', having ensured that workers' rights are guaranteed and that whistleblowers and media freedom are protected. What were those guarantees? 
The term 'whistleblowing' only appears once in the EU Trade Secrets Directive, namely in paragraph 20 of the explanatory memorandum:

The measures, procedures and remedies provided for in this Directive should not restrict whistleblowing activity. Therefore, the protection of trade secrets should not extend to cases in which disclosure of a trade secret serves the public interest, insofar as directly relevant misconduct, wrongdoing or illegal activity is revealed. (2016/943, para 20)

It is important to note that the Trade Secrets Directive refers to freedom of expression and information in the context of investigative journalism (cf. 2016/943, para 19), which like whistleblowing, is intended to form limitations to the secrecy companies can impose. These limitations are specified in Art 5 'Exceptions', which stipulates four conditions that dismiss the imposition of secrecy:

(a) for exercising the right to freedom of expression and information as set out in the Charter, including respect for the freedom and pluralism of the media; (b) for revealing misconduct, wrongdoing or illegal activity, provided that the respondent acted for the purpose of protecting the general public interest;

(c) disclosure by workers to their representatives as part of the legitimate exercise by those representatives of their functions in accordance with Union or national law, provided that such disclosure was necessary for that exercise;

(d) for the purpose of protecting a legitimate interest recognised by Union or national law.

(2016/943, Art 5)

It is clear-albeit not explicit-that Art 5 (b) relates to whistleblowing, whereas Art 5 (a) relates to freedom of the media, and (c) relates trade unions and other forms of worker representation. Abazi (2016) writes that Art 5 provides for situations where information that meets the definition of a trade secret, is nevertheless not considered to be one. Abazi (2016) specifically focuses on Art 5 (b), which provides such exception in the context of whistleblowing, and asserts that the EU Trade Secrets Directive increases the 'susceptibility of whistleblowers despite the exception provide in Art 5, let. (b)' (p. 1071). She gives two reasons for that. The first is that the scope of trade secrets leaves too much discretion to the company that holds the information, to determine "what should be disclosed, to whom and when' (Abazi 2016, p. 1067). The second reason for the increased 'susceptibility' of the whistleblower is that the Trade Secrets Directive puts the burden of proof on the person claiming the exception (i.e. on the whistleblower). The whistleblower needs to prove (a) that information pertains to misconduct, wrongdoing or illegal activity, and (b) that the disclosure is in the 'general public interest'. Abazi (2016, p. 1069) asks 'What is precisely the scope of general public interest'?

Abazi (2016) is of the opinion that the EU Trade Secrets Directive does not provide the necessary legal safeguards for whistleblower protection. Her assertion that the Directive increases 'susceptibility' of the whistleblower implies that it leaves too much discretion with the employer, and not enough freedom with the whistleblower. In other words, the pertinence of which will become clear in the latter part of the paper, the Trade Secrets Directive fails to delineate the 'zone of non-interference' for the whistleblower and thus, makes the 'zone of non-interference' for the employer far too large. Writing in 2016, just after the Trade Secrets Directive was voted in and transposition began, Abazi (2016, p. 1069) saw the Trade Secrets Directive as merely one side of the coin, with a Whistleblowing Directive as the other side of that coin: 'the exception provided in Art 5, let. (b), should be read and understood in the broader legal context of (the missing) whistleblower protection in EU Member States.'

This paper describes and explains how whistleblowing advocates have tried to create a clearly delineated 'zone of non-interference' for whistleblowers in the context of the EU Whistleblowing Directive. It is important to note here that Abazi (2016) only mentions the delineation of 'the general public interest' as the concrete missing piece of the puzzle. However, the 'public interest' delineation was only one fight in the campaign. There was an additional fight, namely around who can be legitimate recipients of whistleblower disclosures. The next section describes and situates these two fights within the campaign by whistleblowing advocates.

\section{Two Fights for Whistleblowing Freedom in the EU}

This section describes the campaign by whistleblowing advocates that has influenced the EU Whistleblowing Directive (2019/1937). Figure 1 presents a timeline for that campaign and thus, for the 'coming about' of the EU Whistleblowing Directive.

In October 2016 a campaigning platform is launched by Eurocadres, a union for people in management positions, together with other unions in Denmark, France, Spain, and ETUC. This platform would later expand to include unions in other European countries as well as civil society organizations campaigning for whistleblower protection (e.g. Transparency International, WIN, Blueprint for Free Speech) and the European Federation of Journalists (EFJ). I attended that inaugural meeting and became part of the email listserv of the platform.

In February 2017, the S\&D group tabled a 'Resolution on the role of whistleblowers in the protection of the EU's financial interests' (2016/2055(INI)), calling the 
Fig. 1 Timeline of the 'coming about' of the EU Whistleblowing Directive

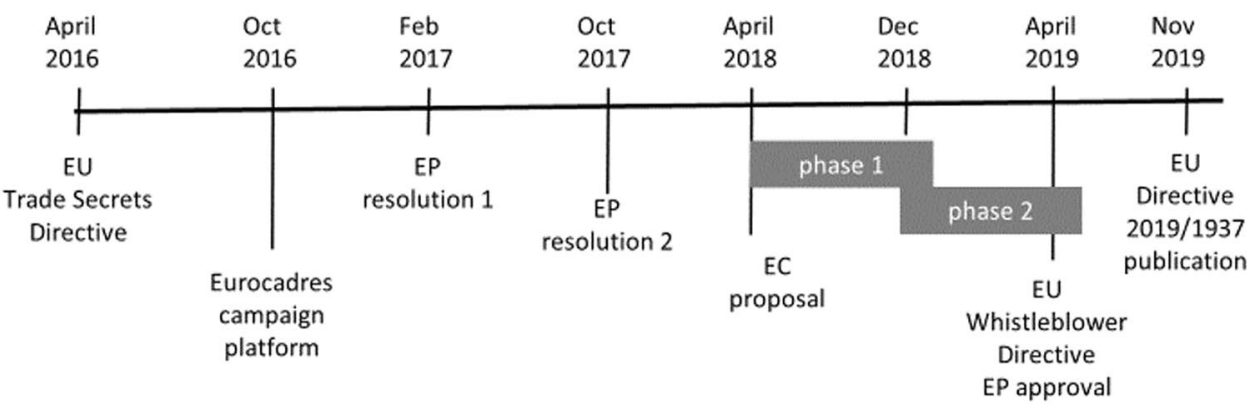

European Commission (EC) to work on a EU Directive on whistleblower protection. In October 2017, it tabled another resolution, now 'on legitimate measures to protect whistleblowers acting in the public interest when disclosing confidential information of companies and public bodies' (2016/2224(INI)).

The email listserv of the platform became very active in January 2018. The EC, more precisely DG JUST was working on a justification study for the EU Directive and needed to be lobbied. That justification study was published in April 2018, along with a proposal for a Directive. What followed was a hectic year of lobbying Commissioners, MEPs, EP advisory committees (such as AFCO, EESC, JURI), and ministers at national level, launching petitions, open letters and holding press conferences. All of this was planned and strategized on the listserv. The platform also held meetings in Brussels, which were announced on the platform. Since many of its members could not attend these meetings, minutes of the meetings were also posted on the listserv.

On 15 April 2019, the EP voted-in the EU Directive on whistleblower protection with an impressive majority. This was an amended version of the proposal the European Commission had tabled a year earlier. The campaigning platform believed it had succeeded in significantly improving the Directive. The Directive entered into force after publication in the Official Journal of the European Union on 26 November 2019, as the 'Directive (EU) 2019/1937 of the European Parliament and of the Council of 23 October 2019 on the protection of persons who report breaches of Union law'.

The research for this paper consists of a document analysis of the two resolutions tabled by S\&D in 2017, the EC proposal text for a Directive of April 2018, the actual votedin text of the Directive of April 2019, and listserv emails of the campaigning platform between January 2018 and April 2019. The document analysis focused on the positions lobbied for by the campaigning platform and how successful these efforts were in establishing freedom in relation to whistleblowing in the EU. The two resolutions from 2017 can be seen as the starting point. The EC proposal from April 2018 is the mid-point, and the final EP text of April 2019 the end-point. The listserv emails contain the debates and struggles faced by the campaigning platform.
The listserv data includes 206 posts made between January 2018 and May 2019. The data provides insights into the strategies of lobbying and the dynamics of collaboration between unions and civil society organizations. It should not be surprising that the conversations on the listserv at times suggest differences in interests and agendas. However, in this paper we focus on two issues the campaigning platform fought for: (1) the material scope of 'public interest', and (2) the three-tiered approach to protected disclosure. I present a chronology of that struggle for each of these topics in turn.

\section{Public Interest}

Whistleblower protection legislation delineates a 'material scope' of wrongdoing for which disclosures are protected. That scope is typically called 'public interest', at least in English. Thus disclosures are protected when they are deemed to be a 'public interest disclosure'. This scope has tended to be restricted to fraud and corruption (Vandekerckhove 2006), and whistleblowing campaigning groups have consistently argued for a widening of that scope. In recent legislation (e.g. in France, Ireland, Serbia) that has been quite successful. In the case of the EU Directive, the scope of public interest was also a site of struggle.

The first resolution (February 2017, 2016/2055(INI)), had the title 'on the role of whistleblowers in the protection of EU's financial interests'. The term 'public interest' was mentioned twice. The second resolution (October 2017, 206/2224(INI)) had the title 'on legitimate measures to protect whistleblowers acting in the public interest when disclosing confidential information of companies and public bodies'. The inclusion of the term 'public interest' in the title of the resolution is a significant shift, in the sense that it makes clear what the agenda is, i.e. this is a call to make the whistleblowing a legitimate exception to secrecy. It is the public interest that justifies exceptions, and that public interest is wider than merely financial interests. It is also noteworthy that the word 'freedom' is not mentioned in the first resolution, but 'freedom of expression' is mentioned in six different sections of the second resolution. That in itself is a departure from the clear separation in the Trade Secrets Directive between on the one hand 'freedom of expression 
and information' and on the other hand 'whistleblowing'. The two are from now onwards inextricably linked.

Now over to the European Commission's justification study for an EU Directive. One of the considerations the European Commission (EC) needs to make in its justification relates to the question of subsidiarity. That means that there must be a good reason why legislating on an issue cannot be left to the Member States. More concretely, the EC needs to identify a 'legal base', i.e. specific article in the Treaty on the Function of the European Union (TFEU) on which variation in the Member State legislation would undermine the functioning of the European Union. The justification study published in April 2018 includes a cost/benefit analysis for four options: (1) status quo, (2) a Commission Recommendation (non-binding), (3) a Directive on whistleblower protection in the area of financial interests of the EU, and (4) a Directive on whistleblower protection in certain areas of EU Law. The justification study opts for option 4, i.e. the broadest one in material scope.

More precisely, the EC proposal for a Directive sets out as material scope: personal data (Art 16 TFEU), customs cooperation (Art 33 TFEU), agricultural policy (Art 43 TFEU), freedom of establishment (Art 50 TFEU), recognition of diplomas and other formal qualifications (Art 53(1) TFEU), transport policy and safety (Art 91 TFEU), transport by rail, road, and inland waterway (Art 100 TFEU), State aid (Art 109 TFEU), internal market (Art 114 TFEU), health (Art 168 TFEU), consumer protection (Art 169 TFEU), tariff (Art 207 TFEU), combatting fraud (Art 325 TFEU). That means that disclosures about wrongdoing relating to any of these could be regarded as 'public interest' and thus protected disclosures.

In May 2018, the platform prepares its first shot at the EC proposal. The coordinating union puts forward a platform text that says that the EC proposal is ambitious but that loopholes need to be closed and that protection of workers and journalists needs to be strengthened. Other unions on the platform disagree with the overall positive tone and request a broadening of the material scope. The platform quickly reaches consensus on getting Art 153 TFEU into the material scope. Article 153 covers working conditions, social security and social protection of workers. Hence, from a union side there is the push to get workers' rights acknowledged as public interest. From the side of civil society organizations, an open letter states that the material scope must include human rights violations, gross waste and gross mismanagement. The open letter refers to 'best practices for whistleblower laws'.

Meanwhile the platform is gearing up its lobbying activities. In June 2018 the platform is informed of a meeting between members of the platform and the EP rapporteur, who is taking up a number of requests, but no mention is made about material scope. In September 2018 the platform is informed that employer demands at the European Economic and Social Committee (EESC), an advisory assembly composed of social partners (employer organizations, trade unions, and representative of other interests), were voted down. These demands would have narrowed down the scope, and the platform takes credit for having stopped that. In October 2018 the platform is informed that the EP's constitutional affairs committee (AFCO) takes the opinion that there cannot be a change to the legal basis of the Directive. Hence, the EP's committee on legal affairs (JURI) will be crucial. However, their vote has been postponed. The platform is also informed that usually JURI follows the EP proposal but this time there might be an exception: the person providing legal services opinion is Axel Voss (EPP, Germany) who has so far not been favourable to the campaign. There remains however a belief amongst platform members that JURI will be open to the possibility of including Art 153 TFEU. A couple of days later JURI indeed forms the opinion that Art 153 is compatible. A week after that the EESC opinion is also that Art 153 must be considered.

Hence the campaign is gaining momentum. The postponed JURI vote takes place on 20 November 2018. JURI takes on the amendment to expand the material scope, which now also includes: 'employment, working conditions, workers' rights on the principle of equal opportunities and treatment between men and women'. On the platform, this news goes out with the title 'Win in EP!', and is seen as a good start for the 'trilogues'.

The trilogues consist of a sequence of substantial and technical meetings between the European Parliament, the European Commission and the European Council. This is where decisions and text are fine-tuned and polished before heading back to the European Parliament to be voted on. In December 2018, the platform is informed of the news that the Council is not in favour of the broad range for the legal basis of the Directive. More precisely, the Council will not want to include Art 153 TFEU without consulting social partners, and there is no time for that now. Given that the EU elections are scheduled for May 2019, an additional consultation round would endanger the whole Directive project. The platform puts its hopes on including Art 153 TFEU in a review of the Directive in 6 years' time. The resulting material scope for whistleblower protection in the EU Directive is left at: protection of personal data, agriculture, freedom of establishment, recognition of diplomas and other formal qualifications, transport, rail road and inland waterway, internal market, public health, consumer interest, environment and fraud. Gone are State aid and tariff, new is environment. 


\section{Three-Tiered Approach}

From December 2018 onwards-after the defeat on public interest-the platform focusses its lobbying activities on the mandatory three-tiered sequence of the EC proposal. This mandatory sequence implies that for whistleblowers to be protected against retaliation, they need to first report the wrongdoing inside the employer organisation, before going outside to a regulator, and they could only disclose to the media after they have reported internally and to a regulator. Before describing how the campaign platform fought on this particular topic, it is necessary to discuss the idea more generally.

The distinction needs to be made between on the one hand a descriptive account of how whistleblowing escalates and on the other hand a prescriptive account of which steps must be taken in the escalation process for the whistleblowing to be legitimate. The descriptive account is most univocal: whistleblowing typically is a gradual escalation of reporting wrongdoing from internal to regulator to a public disclosure. The pattern is consistent across different policy models. Donkin et al. (2008) show that gradual escalation is a typical pattern for whistleblowing in the Australian public sector. Vandekerckhove and Phillips (2019) demonstrate the same for whistleblowers from across different sectors in the UK. Austin and Lombard (2019, p. 82), referring to the SEC annual report of 2017, write that even in jurisdictions with a whistleblower bounty programme, the 'evidence indicates that most whistle-blowers first report internally.'

Prescriptively speaking, there are different approaches. I will demonstrate this multivocality by briefly commenting on three approaches: the US, the UK, and France. In the US, the Dodd-Frank Act provides awards and protection to whistleblowers who report fraud to the SEC. It is important to note- without going into too much detail here-that different law applies to financial award for and protection of whistleblowers, even if both fall within the larger statute of Dodd Frank. Awards are intended to incentivize whistleblowers to come forward, whereas protection programs are intended to provide the whistleblowers with legal remedies as victims of retaliation. The Dodd-Frank legislation itself does not require whistleblowers to have reported internally first. However, the SEC rules do incentivise internal whistleblowing (SEC 2011, p. 231). In deciding what amount the whistleblower will get for their information, the SEC considers favourably when a whistleblower first internally reported the fraud (Austin and Lombard 2019). The rationale is that because the regulator runs an award program for whistleblowers, companies are incentivised to enhance their internal compliance and whistleblowing mechanisms so that the company receives early notification from their workers (Austin and Lombard 2019). Thus, initially the US DoddFrank model incentivized internal reporting without making it mandatory. That was different for the so-called 'gatekeeper professions', i.e. professions who can disrupt wrongdoing by withdrawing their cooperation with the company where the wrongdoing occurs, such as auditors, certified accountants, lawyers, etc. (Gutter 2010). The SEC initially refrained from awarding money to gatekeeper whistleblowers, unless they had blown the whistle 120 days earlier to the board of the company. Recently, the Supreme Court in Dig Realty Trust vs Somers (138 S. Ct. 767(2018)), relied on a 'plain reading' of the Dodd-Frank Act to hold that protection does not extend for internal whistleblowers but extends only to those who report a securities law violation to the SEC' (Heyman 2019). In September 2020, this case led to the SEC rewriting rule $21 \mathrm{~F}-2(\mathrm{~d})(4)$ to now clearly instruct whistleblowers to directly report to the SEC if they want protection and financial award (NLR 2020).

The UK Public Interest Disclosure Act does not have a bounty program like the Dodd-Frank Act has. It is implemented through employment law, and is sometimes said to have two levels of disclosure: to the employer or the regulator in the first instance, and to the wider public as a second level (Bowers et al. 1999). Initially, protection for first level disclosures required the whistleblower to have reported in good faith (Bowers et al. 1999). Second level disclosures, i.e. to the wider public were protected if the worker reasonably believed she would have been victimised, there would have been a cover-up, or the employer or regulator had failed to act on a previous report by the whistleblower. This sounds like a pretty relaxed regime. However, whistleblowers had a hard time at Employment Tribunal to convince the judge of their good faith when they had gone straight to the regulator. In 2013, the good faith test was taken out and replaced by a requirement that the worker had a reasonable belief their whistleblowing was in the public interest, and that it was reasonable for them to blow the whistle to whom they did. Thus, PIDA remains difficult to predict; it protects those whistleblowers of whom the judge finds that they acted reasonably. The approach in France is more rigid. The Sapin II law provided protection for whistleblowers only when they follow a mandatory sequence: internal, to a regulator, wider disclosures.

What about the EU Whistleblowing Directive? In its justification study, which underlies the EC proposal directive, the EC refers explicitly to Vandekerckhove's (2010) articulation. This approach stipulates that regulators need to be mandated to receive reports from whistleblowers in order to intervene when organizations they regulate are not able or not willing to stop wrongdoing that occurs under their responsibility. However, whistleblower reports to regulators are not public disclosures; regulators act on the publics behalf. Public disclosures (e.g. to journalists) also need to be protected so that whistleblowers could warn the public of malfunctioning regulators. Vandekerckhove $(2006,2010)$ aimed to articulate 
the logic of good governance that implicitly underlies policy models found in the early 1990s in Australia (Queensland and New South Wales), but also the UK. It seems that the EC proposal text interpreted Vandekerckhove's three-tiered model through a French lens, as rigidly prescriptive. It thus stipulated that whistleblowers would be obliged to blow the whistle inside their organization first before going elsewhere.

The campaigning platform fought this mandatory internal reporting stipulation. This is where civil society organizations got the upper hand within the platform. Before 2018 unions held the view that the mandatory tiered sequence provisions were not the main problem-the material scope was-and that some rewording of exception to the obligation to go internally first would suffice. WIN had first tabled concerns about the mandatory tiered sequence in June 2018. From then on, both material scope and tiered sequence were campaigning positions. In October 2018 WIN provides the platform with a couple of one-pagers, basically argumentative ammunition against a mandatory tiered sequence. The brief states that.

mandatory internal reporting would undermine the Directive's goal by increasing the opportunities for retaliation and enabling obstruction of justice. It would be contrary to many established justice systems for a whistleblower to lack the certainty that they are able to turn to competent authorities without reprisal. (WIN brief 181017)

WIN had produced these briefs in August 2018, but only now starts to promote these through the platform. As with the material scope issue around this time, EP committees seem prepared to move away from mandatory internal reporting, and so does AFCO.

As already noted, in December the route to a wider material scope is closed off, and the platform now fully takes up the attack on the mandatory tiered sequence. In January 2019 the platform is briefed on how Member States representatives stand with regard to the mandatory tiered sequence. Apparently Germany and France want to keep it. Moreover, the Council text, which forms the bases for the trilogues also keeps the mandatory tiered sequence. In response, Eurocadres and other unions plan to increase pressure by launching a public petition. Early February 2019, Tom Devine from GAP issues a text to the platform on 'poison pills' and 'cardboard shields' in whistleblower protection. His analysis includes the following:

Mandatory internal reports in any form enable obstruction of justice at bad faith organizations, because they lock in a three month grace period to perfect a cover-up. While the proposal has a relevant exception, there is an inherent chilling effect from barring the clear, free choice of audience. Until the whole case is over, employees would not know whether they waived their rights by going straight to authorities. This is highly uncertain. As the recital explains, at 23, whether the exception applies "will thus depend on the circumstances of each case and of the nature of the rules that have been breached."

A week later, the platform publishes an open letter on the mandatory tiered sequence, using Devine's imagery of the shield (see Fig. 2). The platform also issues a call on members to lobby ministers at national level, in particular ministers of justice. Meanwhile, Blueprint for Free Speech launches a parallel public petition, which is not taken all that well by the unions, who call for unity.

At the end of February 2019, the platform signals that there might be a blocking minority in the Council: 10 Member States now oppose the mandatory tiered sequence; Germany and France still want it. At the beginning of March, positions in the Council seem entrenched but the petitions together gathered 250,000 signatories. A couple of days later, Eurocadres reports some opening at COREPER (the committee of permanent Member State representatives) in the Council. On 11 March the platform informs that there is a 'breakthrough' on tiered sequence in the trilogues. Germany and France have caved in. The text can now be amended and sent to the EP for voting.

On 15 April there is a huge wave of celebrating messages and mutual congratulations on the listserv after the successful vote in the EP. Four days before this, Julian Assange was arrested in London.

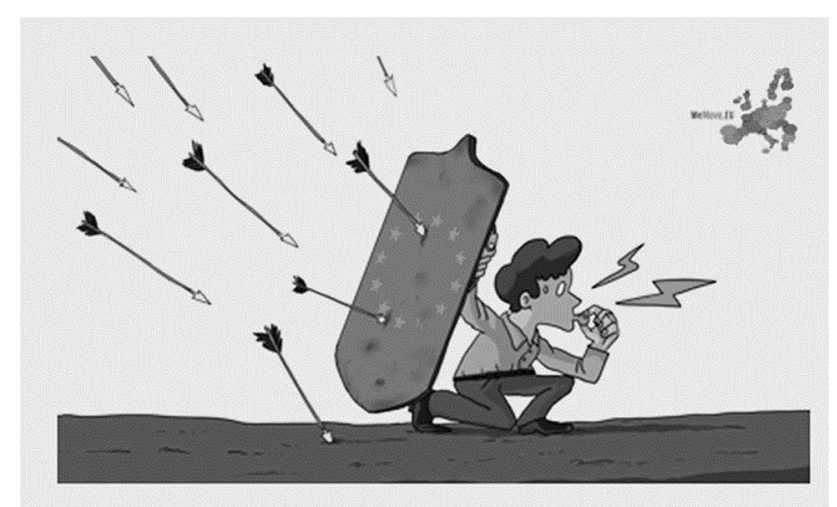

Fig. 2 Image issued by the platform with the open letter February 2019 (black/white reproduction, used with permission of Government Accountability Project) 


\section{Discussion: Is It Freedom?}

Let's recap. The 'coming about' of the EU Whistleblowing Directive starts with the voting in of the EU Trade Secrets Directive. Hence, we start from secrecy and too much employer discretion to impose secrecy, which needs to be pushed back by clarifying what the public interest is (Abazi 2016). In other words, The Trade Secrets Directive created too much legitimate interference with freedom of expression and information, and the Whistleblowing Directive needs to carve out a 'zone of non-interference'. I have described the activities and struggles of a campaigning platform to carve out such a zone of freedom. I have described how the unions took the lead in fighting for a delineation of 'public interest' and the whistleblowing activist staged a fight over the mandatory sequence of reporting wrongdoing. In this section I will use the work of Berlin and Skinner to situate these two fights with regard to freedom.

Before I do that, it is interesting to look at the use of the word 'freedom' in the documents en route to the EU Whistleblowing Directive. The Trade Secrets Directivethe start of that route-made a clear separation between freedom of expression (Art 5a of 2016/943) and public interest disclosures (Art. 5b of 2016/943). The EC justification study states that (p. 32) the general objective is to address underreporting of breaches of EU law, and that this will 'in turn have ancillary benefits' such as protection of fundamental rights, and in that sense enhance freedom of expression. The protections it offers to whistleblowers are based on the principles provided in the ECtHR case law on freedom of expression (ECHR Art 10). In the EC proposal text of April 2018, the word 'freedom' occurs 23 times in the following combinations: freedom of expression, media freedom, freedom to conduct a business, freedoms of others. Very often 'freedom of expression' and 'media freedom' are used together as one expression. In the adopted text of the Directive (April 2019), the word 'freedom' occurs 17 times in the following combinations: freedom of expression, media freedom, free movement of goods, freedom to provide services, freedoms of others, freedom to conduct a business. The terms 'freedom of expression' and 'media freedoms' are less often part of the same expression.

Whilst this is interesting, it does not really answer the question philosophically. There has been a clear attempt to make the link between freedom of expression and information on the one hand and whistleblowing on the other, but the end result does not seem particularly strong. But that is when we look at word frequency. However, in the two subsections that follow now, I use Berlin and Skinner to make clear in what way the link between freedom and whistleblowing has gained deep ties in the EU Whistleblowing Directive. Perhaps not in word count but definitely in public interest and autonomy.

\section{The Zone of Public Interest}

Berlin writes that it is the absence of deliberate interference by others which is essential to freedom. Thus freedom is a negative notion and is 'a situation in which others do not interfere with my actions' (Berlin 2014, p. 183). Hence, 'the wider the area of non-interference the wider my freedom' (ibid.). Berlin readily acknowledges that this line of thinking is Hobbesian, and that consequentialist philosophers debate over how wide or narrow that 'area of non-interference' should be-Berlin mentions Bentham and Mill but we could argue that much of political philosophy is a continuation of such 'haggling' (Berlin 2014, p. 184). However, they do not disagree that freedom is limited somewhere. In a Hobbesian argument, we accept a limit to our freedom because we know that all others have their freedom limited in the same way. In that sense our freedom does not depend on our power; Berlin writes that the 'liberty of the weak depends on restraint of the strong' (Berlin 2014, p. 185).

Indeed, that is where we started: the Trade Secrets Directive leaves the employer unrestrained; freedom of the whistleblower can be attained by delineating a zone of non-interference. I submit here that the fight over the material scope of the EU Directive was an instance of disagreement about how wide the area of non-interference should be. Whistleblower legislation puts in place an area where people who disclose information about wrongdoing cannot be interfered with. The material scope of whistleblowing legislation carves out the type of wrongdoing about which disclosures must not be interfered with. Thus, the fight over how broad the material scope should be, is a fight over how wide the area of non-interference should be.

How exactly was this fight staged? In May 2018, the campaigning platform reached the position, quite soon after the EC published its proposal text, that Article 153 TFEU should be included in the legal base of the EU Directive. This would widen the material scope to also include disclosures about wrongdoing related to working conditions and social protection of workers. That would have amounted to an important widening, especially considering the trade secrets background of the EU Whistleblowing Directive and the coming together of unions and whistleblower activists.

Meanwhile, civil society voices were also chipping in. WIN's open letter in June 2018 argues that the material scope should include human rights violations. The letter also includes a fascinating passage on freedom, namely that whistleblower protection is about freedom of expression, which is necessary to hold powers accountable. Hence, in Berlin's lingo, WIN is arguing that whistleblower protection 
is about creating an area of non-interference for people to interfere when others harm society. Does Berlin talk about that? Very much so. It is at the core of the notion of negative freedom. As Skinner points out, Berlin's core is Hobbesian: we obey limitations to our freedom because the others face the same limitations. Or, if everyone can blow the whistle on someone else, then the powerful will not be able to get away with harming others. The freedom of the powerful is limited by the freedom to blow the whistle on them. That is WIN's argument in the claim that freedom of expression holds those in power accountable. It is also what the unions call for when they want Article 153 FTEU to be part of the material scope, albeit in a more institutionalized phrasing. If disclosures of wrongdoing related to worker's rights are within the area of non-interference, unions will have more power to do what they do, i.e. block capital's interference with labour. However, the fight for including Article 153 FTEU in the material scope of the EU Directive was not successful. It nevertheless was a fight over widening the area of freedom.

What to say about the use of the term 'public interest'? In the 26 month trajectory between the first resolution in February 2017 to the voted-in text of the Directive in April 2019, it is the second resolution from October 2017 that peaks in the use of term 'public interest'. The debate then moves on using concrete legislative articles (e.g. Art 153 TFEU). Talk of a 'public interest' remains vague, and the evolution from Resolution to EU Directive can be seen as one of making the delineation of the area of freedom less vague.

But that is not all. So far, in discussing the 'zone of noninterference' for whistleblowing in the EU Whistleblowing Directive, I have looked at the fight over the 'zone', i.e. Abazi's (2016) question 'what is the public interest?'. The remaining question relates to what can be understood by 'non-interference'. In the context of whistleblowing, interference is retaliation. Retaliation against whistleblowers, whatever form it might take, are attempts to silence people or to kick them out of their professional recognition and standing (Kenny 2019; Weiskopf and Tobias-Miersch 2016). There was not particularly a big fight over this in the coming about of the EU Whistleblowing Directive, but it is worth mentioning that in the directive, retaliation is defined as.

any direct or indirect act or omission which occurs in a work-related context, is prompted by internal or external reporting or by public disclosure, and which causes or may cause unjustified detriment to the reporting person; (2019/1937, Art 5. 11)

Measures for protection against retaliation and for support of the whistleblower (Chapter VI of 2019/1937) are wide, include not only actual behaviours and omissions but also threats, and also apply to third persons associated with whistleblowers. It would be out of scope for this paper, I believe, to discuss each of these, especially since I am focusing in this paper on what appeared to be the big fights. It is however important to point out that 'interference' can also be disinformation. To that end, the EU Whistleblowing Directive obliges all organisations with more than 50 employees to have internal whistleblowing policies and confidential channels for reporting (Art. 8 and 9 of 2019/1937). But again, there wasn't really a fight over any of this.

But what about the mandatory tiered sequence? I wrote that this was the second big fight besides the material scope. That is something where I believe Quentin Skinner's take on Berlin's delineation of negative freedom can give us some insight into how important that point really was. I do that next.

\section{Mandatory Sequence and Autonomy}

In his Isaiah Berlin Lecture at the British Academy in 2001, Skinner argues that by echoing Hobbes, Berlin discredits a formulation of negative liberty that was used by the early seventeenth century revolutionaries promoting 'the cause of Parliament against the crown and to legitimize the execution of King Charles I' (Skinner 2002, p. 247). Thus, Skinner casts Hobbes as a counter-revolutionary. He then draws a lineage from Hobbes notion of negative liberty (which Berlin echoes) to the rise of utilitarianism and its hegemony in the 'conceptual space' of liberty.

Skinner wants to 'lift back to the surface' this alternative notion, which I believe is pertinent for the whistleblowing campaign in the EU. What is that notion? It is the position that equals living a life in dependence of the power of someone else to living in a state of servitude, and further equals living in servitude to a lack of freedom. Skinner derives this position from the writings of the 17th Century Parliamentarians who were critics of the royal prerogative. He also locates it in Roman political thought. Thus, freedom is 'restricted not only by actual interference or the threat of it, but also by the mere knowledge that we are living in dependence on the goodwill of others' (Skinner 2002, p. 247). It is not the possibility of such arbitrary interference but the awareness of living under arbitrary power that makes us unfree.

Berlin distinguishes his two concepts of liberty on the source of what limits freedom. In negative freedom the source of limit to my freedom are the others; in positive freedom I am my own source of limits to my freedom but that coincides with what I want. The remainder of Berlin's paper is mainly spent on arguing what freedom is not. For example, equality and justice are just as important goals, Berlin notes, but they are not the same as freedom. Berlin also makes the point that in evaluating freedom as good, we must not confound it with other notions we regard as good.

The difference is more than a semantic detail. Now, Skinner's notion is not Berlin's positive freedom because I do not 
want my state of servitude. Nevertheless, it is my awareness of my dependence that makes me act differently to how I want to. One might argue that in Skinner's notion of negative freedom I am the source of my unfreedom albeit that my unfreedom is self-censorship rather than self-mastery. So there are two notions of negative liberty: where Berlin insists that freedom is limited by coercion, Skinner claims that it can also be limited by servitude.

Back to the EU Whistleblowing Directive and the campaign. At first sight, the struggle over the mandatory sequence of recipients does not seem to be over a widening of the area of non-interference. The three tiers were there from the start, and are still there. What was removed is the mandatory sequencing in order for the whistleblower to find protection. Hence, is this about freedom, about security or about autonomy?

From a legal perspective, the approved text (no mandatory sequence) does not provide more security in terms of predictability. There is a bit of a paradox here. One the one hand, if one follows the mandatory steps one is more likely to know that protection will be granted than currently, when one will need to argue proportionality and reasonable belief. On the other hand, following a mandatory sequence can make the whistleblower prone to arbitrariness and interference of the employer or the regulator. It would have put us back to Abazi's (2016) comment that too much discretion is left to the employer to decide what needs to be secret for whom. And that was precisely what was wrong (or incomplete) with regard to the Trade Secrets Directive. Thus, restraining that discretion-carving out the zone of non-interference-is not done only through delineating the 'zone' but also through delineating 'non-interference'.

From a sociological and psychological perspective, there is a strong case to argue that this struggle was about autonomy. The whistleblower takes power by speaking up, but loses that power when they are neglected, when they need to wait for 3 months before being able to take it further (Kenny 2019; Kenny et al. 2018). The platform argued that it needed to be for the whistleblower to decide, that it had to be left in their hands. Hence, if the whistleblower takes up power to speak up, they need to maintain their autonomy. The civil society organizations on this campaigning platform cast that autonomy as a freedom of expression to hold others to account. The conceptual linking of autonomy and freedom found in this paper is similar to the one Skinner mentions. This is about not being dependent on someone else whose power is based on the discretion they have over people's decisions. Perhaps the struggle studied in this paper is an even better example than Skinner's. Devine pointed out in his analysis that what he called 'poison pills' (i.e. instances of discretion over the legitimacy of whistleblowers' decisions) in the Council text would lead to law suits against whistleblowers. There can be little doubt that being taken to court as an individual by a resource rich organization (at least comparatively speaking) is 'interference by others'. Thus, in the context of whistleblowing, fighting for autonomy is fighting for freedom.

\section{Conclusion}

In this paper, I have described how the coming about of the EU Directive on whistleblower protection was a making-moresecure of the freedom hinted at in the EU Trade Secrets Directive. In making that freedom more secure, it was necessary to fight for specific delineations of a 'zone of non-interference' for whistleblowing. I described how a campaigning platform of unions and whistleblowing activists fought on two main fronts: delineating the material scope for the EU Whistleblowing Directive as the 'zone' of what counts as the public interest, and making an important change with regard to "non-interference' compared to the EC proposal, namely getting rid of the mandatory sequence for escalating whistleblowing reports. Looking back at the EU Trade Secrets Directive, the fight over the mandatory sequence might have seemed like a detail. Yet, it is an important element for whistleblowing freedom. I used Berlin and Skinner to make clear just how important.

Berlin argues that security and autonomy are not freedom; Skinner argues that insecure freedom is dependency and thus slavery. Skinner's historical example is one in which arbitrariness in overruling someone's decision is a lack of autonomy. That is the opposite of freedom because being at someone else's discretion is not being free. I have argued that, in its fight to get rid of the mandatory sequence, the whistleblowing campaign is a contemporary example of what Skinner points at, namely that it does not make sense to talk about freedom without autonomy. In whistleblowing, freedom of information is crucial and implies the whistleblower has the right to impart information. This right not only extends to information in the public interest but also implies that the whistleblower maintains autonomy in the choice of who receives the information.

\section{Compliance with Ethical Standards}

Conflict of interest The author declares that there is no conflicts of interest.

Ethical Approval This paper uses publicly available data and was conducted in compliance with the Declaration of Helsinki (2013) on research ethics.

Open Access This article is licensed under a Creative Commons Attribution 4.0 International License, which permits use, sharing, adaptation, distribution and reproduction in any medium or format, as long as you give appropriate credit to the original author(s) and the source, provide a link to the Creative Commons licence, and indicate if changes were made. The images or other third party material in this article are included in the article's Creative Commons licence, unless indicated otherwise in a credit line to the material. If material is not included in 
the article's Creative Commons licence and your intended use is not permitted by statutory regulation or exceeds the permitted use, you will need to obtain permission directly from the copyright holder. To view a copy of this licence, visit http://creativecommons.org/licenses/by/4.0/.

\section{References}

Abazi, V. (2016). Trade secrets and whistleblower protection in the European Union. European Papers, 1(3), 1061-1072.

Austin, J., \& Lombard, S. (2019). The impact of whistleblowing awards programs on corporate governance. Windsor Yearbook of Access to Justice/Recueil annuel de Windsor d'accès à la justice, 36, 63-83.

Berlin, I. (2014). Freedom and its betrayal (2nd ed.). Princeton: Princeton University Press.

Bouville, M. (2008). Whistle-blowing and morality. Journal of Business Ethics, 81(3), 579-585.

Bowers, J., Mitchell, J., \& Lewis, J. (1999). Whistleblowing: The new law. London: Sweet and Maxwell.

Brown, A. J., Moberly, R. E., Lewis, D., \& Vandekerckhove, W. (2014). International handbook on whistleblowing research. Cheltenham: Edward Elgar.

Donkin, M., Smith, R., \& Brown, A. J. (2008). How do officials report? Internal and external whistleblowing. In A. J. Brown (Ed.), Whistleblowing in the Australian public sector. Enhancing the theory and practice of internal witness management in public sector organisations (pp. 83-108). Canberra: ANU Press.

Dworkin, T. M., \& Callahan, E. S. (1998). Buying silence. American Business Law Journal, 36, 151-191.

Fasterling, B., \& Lewis, D. (2014). Leaks, legislation and freedom of speech: How can the law effectively promote public-interest whistleblowing? International Labour Review, 153(1), 71-92.

Gutfleisch, M. G. (2018). Employment issues under the European Trade Secrets Directive: Promising opportunity or burden for European companies? European Company Law, 15(5), 175-181.

Gutter, E. (2010). Whistleblowers under the Dodd-Frank Act and their impact on gatekeepers. Review of Banking \& Finance Law, 30, 753-783.

Hassink, H., De Vries, M., \& Bollen, L. (2007). A content analysis of whistleblowing policies of leading European companies. Journal of Business Ethics, 75(1), 25-44.

Heyman, S. B. (2019). Digital realty trust v. somers: Whistleblowers and corporate retaliation. Roger Williams University Law Review, $24,78-103$.
Kenny, K. (2019). Whistleblowing. Toward a new theory. Cambridge: Harvard University Press.

Kenny, K., Fotaki, M., \& Vandekerckhove, W. (2018). Whistleblower subjectivities: Organization and passionate attachment. Organization Studies. https://doi.org/10.1177/0170840618814558

Larmer, R. A. (1992). Whistleblowing and employee loyalty. Journal of Business Ethics, 11(2), 125-128.

Near, J. P., \& Miceli, M. P. (1985). Organizational dissidence: The case of whistle-blowing. Journal of Business Ethics, 4(1), 1-16.

NLR. (2020). The SEC whistleblower rule changes explained. The National Law Review 10(272). Retrieved September 28, 2020, from https://www.natlawreview.com/article/sec-whistleblowerrule-changes-explained.

SEC. (2011). Whistleblowers incentive and protections final rules, Doc 17 CFR Parts 240 \& 249. Retrieved August 12, 2011, from https ://www.sec.gov/rules/final/2011/34-64545.pdf [SEC Final Rules].

Skinner, Q. (2002). A third concept of liberty. In Proceedings of the British Academy, vol. 117, (pp. 237-268).

Tsahuridu, E. E., \& Vandekerckhove, W. (2008). Organisational whistleblowing policies: Making employees responsible or liable? Journal of Business Ethics, 82(1), 107-118.

Vandekerckhove, W., \& Commers, M. R. (2003). Downward workplace mobbing: A sign of the times? Journal of Business Ethics, 45(1-2), 41-50.

Vandekerckhove, W. (2006). Whistleblowing and organizational social responsibility. Burlington: Ashgate.

Vandekerckhove, W. (2010). European whistleblower protection: Tiers or tears? In D. Lewis (Ed.), A global approach to public interest disclosure (pp. 15-35). Cheltenham: Edward Elgar.

Vandekerckhove, W. (2016). Freedom of expression as the "broken promise" of whistleblower protection. La Revue des droits de l'homme. https://doi.org/10.4000/revdh.2680

Vandekerckhove, W., \& Phillips, A. (2019). Whistleblowing as a Protracted Process: A Study of UK Whistleblower Journeys. Journal of Business Ethics, 159(1), 201-219.

Weiskopf, R., \& Tobias-Miersch, Y. (2016). Whistleblowing, parrhesia and the contestation of truth in the workplace. Organization Studies, 37(11), 1621-1640.

Publisher's Note Springer Nature remains neutral with regard to jurisdictional claims in published maps and institutional affiliations. 